\title{
Egg production and energy storage in relation to feeding conditions in the subantarctic calanoid copepod Drepanopus pectinatus: an experimental study of reproductive strategy
}

\author{
F. Alonzo ${ }^{1, *}$, P. Mayzaud ${ }^{1}$, S. Razouls ${ }^{2}$ \\ ${ }^{1}$ Observatoire Océanologique, Océanographie Biochimique et Ecologie, LOBEPM - ESA-CNRS 7076, BP 28, \\ 06230 Villefranche-sur-Mer, France \\ ${ }^{2}$ Laboratoire Arago, Observatoire Océanologique, URA-CNRS 117, 66630 Banyuls Cedex, France
}

\begin{abstract}
The egg production and the hatching success of Drepanopus pectinatus (Brady, 1883) was examined in relation to food availability. The spawning frequency did not change in relation to the concentration of phytoplankton with an interval time of $7.6 \mathrm{~d}$ between 2 broods. At least 1 egg sac was produced per female in almost all cases (>93\%) independent of the food level. The subsequent recruitment of breeding females was strongly influenced by feeding conditions: only 22 to $50 \%$ of the starved females completed 3 successive breeding cycles, while $100 \%$ of the fed females did. The number of eggs per was also affected by the concentration of food, with a mean of 12 eggs per sac in starved females and 19.4 eggs per sac in fed females independent of the food level. Brood sizes increased significantly in the fourth breeding cycle to 35.3 eggs per sac in females fed a concentration of $1180 \mu \mathrm{g}$ protein $\mathrm{l}^{-1}$. Egg-hatching time was constant, with an average of $6.7 \mathrm{~d}$. To evaluate the relative roles of reproduction and of accumulation of energy reserves, we compared the production of eggs and the changes in the organic composition of females in various limiting food conditions. Brood size was influenced by both immediate and past trophic conditions, with the number of eggs per sac varying from 10.1 to 12.8 . The content of the eggs was constant: $122 \mathrm{ng}$ of protein and $234 \mathrm{ng}$ of lipids. In females, protein content was a good indicator of immediate feeding conditions, while lipids, dominated by wax esters, reflected both immediate and past feeding conditions. A low level of egg production was maintained throughout periods of nutritional limitation or starvation. Subsequently, food was used to reduce the consumption of the energy reserves of females before being invested in reproduction, as observed at high food concentration.
\end{abstract}

KEY WORDS: Drepanopus pectinatus - Egg production · Energy reserves - Food availability · Limitation Resale or republication not permitted without written consent of the publisher

\section{INTRODUCTION}

Drepanopus pectinatus (Brady, 1883) was described as a species endemic to the Indian sector of the Southern Ocean (Hülsemann 1985), and it dominated the coastal and neritic copepod community in Kerguelen Archipelago. In the Morbihan Bay, this herbivorous copepod represented from 73 to more than $99 \%$ of the

*E-mail: alonzo@obs-vlfr.fr total number of copepods according to season (Razouls \& Razouls 1988, Razouls et al. 1996). D. pectinatus, due to its dominant biomass and trophic position, plays a key role in the food-web of the subantarctic pelagic coastal ecosystem as the predominant consumer of phytoplankton and main potential prey of the predatory calanoid Paraeuchaeta antarctica (Yen 1991).

The relationship between the reproduction of herbivorous copepods and their supply of food is an important parameter. Limiting food conditions have

(C) Inter-Research 2001 
been shown to influence egg production and growth, and the possible occurrence of those conditions in the field would have a strong impact on secondary production. At high latitudes, species have adapted their life cycles to the period of nutritional limitation induced by the seasonality in food availability (Conover 1988). Studies performed on a wide variety of species illustrated the diversity of reproductive strategies. In the Southern Ocean, reproduction and development of Rhincalanus gigas (Ommaney 1936) and Calanoides acutus (Andrews 1966) occurred in summer during the period of maximal food availability. A similar pattern was found for Calanus finmarchicus from northern Norway (Diel \& Tande 1992). In the arctic copepods Calanus hyperboreus and Calanus glacialis (Smith 1990) and in the antarctic species Calanoides acutus (Huntley \& Escritor 1991), egg production was independent of ambient food and related to accumulated lipids. In the subantarctic herbivorous copepod Neocalanus tonsus (Ohman 1987) and in C. glacialis from the Barents Sea (Hirche \& Kattner 1993) pronounced differences were observed between generations. Overwintering females used their stored lipids as an energy source to release eggs, whereas newly moulted females required a particulate food source.

It has been demonstrated that calanoid copepods store energy reserves, predominantly as wax esters (Lee et al. 1971, Sargent \& Henderson 1986). Those energy reserves were shown to support egg production when food availability was low and to allow organisms to reproduce independently from immediate nutritional needs (Ohman et al. 1989). The large lipid accumulation recorded in Drepanopus sp. (Lee \& Hirota 1973) may play a similar role in reproduction. The life cycle of $D$. pectinatus was studied in the Kerguelen Archipelago. The observed seasonal abundance and size distribution of developmental stages (Razouls \& Razouls 1988, 1990) showed that the species completed 4 generations $\mathrm{yr}^{-1}$, with a period of major abundance in summer. The reproductive biology of $D$. pectinatus remains less well known mainly because of the difficulties in accessing these parts of the World Ocean.

In the present study, egg production and hatching success are examined in relation to food availability. The biochemical contents of females are investigated in conjunction with reproduction for a range of limiting food conditions. Our aim is to estimate the relative contribution of food supply and accumulated reserves to the reproductive energy budget during spring and summer. The question of whether females prioritize energy storage or production of eggs during the phytoplankton bloom will improve our understanding of the reproductive strategy of Depanopus pectinatus in the Kerguelen Archipelago.

\section{Materials and methods}

Sample collection. Drepanopus pectinatus samples were collected in the Morbihan Bay at IOZ (Interaction-Oiseaux-Zooplancton) Stns 1 (49 $\left.42^{\prime} \mathrm{S}, 70^{\circ} 03^{\prime} \mathrm{E}\right)$ and $2\left(49^{\circ} 43^{\prime} \mathrm{S}, 70^{\circ} 15^{\prime} \mathrm{E}\right)$ during the summer phytoplankton bloom (December 1996 to January 1997) using a WP2 net (0.59 m diameter; $200 \mu \mathrm{m}$ mesh aperture). The copepods were obtained by short surface hauls and transferred back to the laboratory for experiments. Copepod mortality remained well below $5 \%$ $\mathrm{d}^{-1}$ in all experiments.

Feeding conditions. The diatom Thalassiosira weissflogii (in exponential growth) was used as food. Algal batch cultures were grown at $14^{\circ} \mathrm{C}$ under a $12: 12 \mathrm{~h}$ light:dark cycle in F/2 media (Guillard \& Ryther 1962). Cell concentration was determined every $3 \mathrm{~d}$. Protein and chlorophyll a concentrations were measured on the day the culture was used for experiments. Cultures were diluted with $0.45 \mu \mathrm{m}$ filtered seawater to achieve different food levels: 'High', 16000 cells ml ${ }^{-1}(1180 \mu \mathrm{g}$ protein $\mathrm{l}^{-1}$ ); 'Medium', 4800 cells $\mathrm{ml}^{-1}$ (354 $\mu \mathrm{g}$ protein $\mathrm{l}^{-1}$ ) and 'Low', 1600 cells $\mathrm{ml}^{-1}\left(118 \mu \mathrm{g}\right.$ protein $\left.\mathrm{l}^{-1}\right)$. The corresponding lipid supply was calculated assuming a lipid to protein ratio of 0.26 estimated separately from a culture in exponential growth.

Egg production dynamics and hatching success. The breeding stages previously defined for Paraeuchaeta antarctica (Alonzo et al. 2000) were suitable to the Drepanopus pectinatus breeding cycle: egg-bearing females (i.e. carrying 1 egg sac) and interbrood females (i.e. those females in the interval between 2 broods). The prespawning stage was not considered, as developing eggs visible in the ovarian diverticula became visible only a few hours before deposition.

Interbrood females were placed individually in $50 \mathrm{ml}$ of $0.45 \mu \mathrm{m}$ filtered seawater and maintained at sea temperature $\left(6^{\circ} \mathrm{C}\right)$. To investigate a possible influence of feeding conditions on the egg production dynamics and hatching success, the copepods were either starved or fed at 'High' and 'Medium' food levels. To maintain an approximately constant food level in the $50 \mathrm{ml}$ vials, food media and filtered seawater were renewed every $2 \mathrm{~d}$. Every day females were examined, and their times of egg deposition and egg hatching were noted. The duration of egg-bearing stages and the interval between production of 2 successive sacs were calculated. Egg-bearing females were examined for egg hatching. As soon as the eggs hatched, females were removed and placed in a new $50 \mathrm{ml}$ vial. Nauplii and undeveloped eggs were counted and their respective proportions calculated.

Limiting food conditions. This experiment was designed to investigate a possible influence of limiting food conditions on brood size and on the organic con- 
tents of females and eggs. Groups of 50 interbrood females were placed in 11 jars with $0.45 \mu \mathrm{m}$ filtered seawater. The jars were attached to a rotating wheel and maintained at sea temperature $\left(6^{\circ} \mathrm{C}\right)$. Energy reserves may not have been the same between females at the beginning of the experiment (as a result of different trophic histories in the field), and this difference may have interfered with the detection of any influence caused by limiting food conditions. To avoid this eventuality, half of the females were starved for $2 \mathrm{wk}$ in $0.45 \mu \mathrm{m}$ filtered seawater before the experiment and those that produced an egg sac were removed. This preliminary starvation was performed to reduce the variability in the organic content of females. The other half of the females were acclimated to laboratory conditions overnight in natural seawater.

To induce the limiting food conditions, we preferred to reduce the frequency of food renewal rather than maintain a constant low concentration of phytoplankton. This procedure had the advantage of preventing stress for the females and avoiding the risk of egg sac loss associated with a daily change of media. Groups of pre-starved or acclimated females were either starved or fed at 'High', 'Medium' or 'Low' food levels. Jars were collected after 1 or $2 \mathrm{wk}$. In the jars held for $2 \mathrm{wk}$, food levels were readjusted at the end of the first week to their initial value. This experiment was repeated in December 1996 and in January 1997.

Brood size and biochemical content of females and eggs. In each experimental jar, the dead copepods and the interbrood and egg-bearing females were counted and their respective proportions calculated. The number of eggs per sac was counted for 15 egg-bearing females. The egg-bearing females with their egg sacs and the interbrood females were frozen and kept at $-80^{\circ} \mathrm{C}$ until analyses. The seawater was $0.45 \mu \mathrm{m}$ filtered on Whatmann GF/C glass-fiber filters to determine the remaining concentration of chlorophyll $a$.

For each experimental condition, the eggs were separated from the females and pooled. Protein and lipid extracts (in triplicate) of the interbrood females, of the egg-bearing females (without their egg sacs) and of the eggs were performed separately. One to 14 females and 12 to 70 eggs were used for 1 lipid extraction. Total lipids were extracted according to Bligh \& Dyer's method (1959) modified by Mayzaud \& Martin (1975). The Nile red spectrofluorometric method was used to quantify neutral and polar lipids in females, with the standard equations specifically established for Drepanopus pectinatus (Alonzo \& Mayzaud 1999). In D. pectinatus, neutral lipids were mainly wax esters and a small proportion of triacylglycerols. Polar lipids were essentially phospholipids. The procedure for staining and fluorescence measurement (4 replicate measurements per extraction) is described in Alonzo et al.
(2000). Lipid content of eggs was quantified using the ultramicro method described by Pande et al. (1963) with cholesterol as standard (3 replicate measurements per extraction). One female and 7 to 35 eggs were required for a protein extraction. Protein was extracted in $0.1 \mathrm{M}$ sodium phosphate buffer at $\mathrm{pH} 8$. Fluorometric quantifications of protein (3 replicate measurements per extract) were performed using fluorescamine as a probe (Böhlen et al. 1973) and bovine serum albumin as standard.

Estimation of mean ingestion. Copepod ingestion was calculated from changes in chlorophyll a concentration after 1 or $2 \mathrm{wk}$. Algal growth rates (i.e. grazing controls) were determined from changes in cell densities in samples of food without copepods incubated under similar conditions. To investigate a possible change in the quality of the food, the concentrations of protein and of chlorophyll a were determined in the control jars after 1 and 2 wk. The phytoplankton was filtered on Whatmann GF/C filters (precombusted for protein assays). Protein was extracted (in triplicate) in $\mathrm{NaOH} 0.5 \mathrm{~N}$ and quantified using a bicinchoninic acid (BCA) reagent kit for protein assays (Pierce Chemical Company) with bovine serum albumin as a standard. Similarly, chlorophyll a was extracted (in triplicate) in $90 \%$ acetone (Neveux 1976) and quantified using the fluorometric method described by Yentsch \& Menzel (1963) as modified by Holm-Hansen et al. (1965). Concentrations were calculated with the equations of Lorenzen (1966).

Estimation of the number of broods. Estimating the number of broods produced in 11 jars was made more complex since females were not examined on a daily basis. Therefore, at sampling time, interbrood females as well as egg-bearing females might have already released 1 or several broods. The number of broods $B(t, C)$ produced at time $t$ and mean food concentration $C$ was estimated using the equation:

$$
\begin{aligned}
& B(t, C)=n_{\text {egg-bearing }} \cdot \sum_{i} i \cdot p_{i}(t, C)+n_{\text {interbrood }} \cdot \sum_{i} i \cdot q_{i}(t, C) \\
& {\left[\sum_{i} p_{i}(t, C)=1 \text { and } \sum_{i} q_{i}(t, C)=1\right]}
\end{aligned}
$$

where $n_{\text {egg-bearing }}$ and $n_{\text {interbrood }}$ are the number of females in egg-bearing and interbrood stages respectively observed in the jar at time $t$ and concentration of food $C, p_{i}(t, C)$ is the proportion of egg-bearing females carrying their $i$ th egg sac and $q_{i}(t, C)$ is the proportion of interbrood females having produced $i$ egg sacs. $p_{i}(t, C)$ and $q_{i}(t, C)$ were provided by the reproduction dynamic study.

Dry weight and biochemical composition of females in situ. Body weight, protein and lipid contents of interbrood females were determined in situ at each date of capture. Values were further used as initial 
conditions to calculate the changes in energy reserves of the females during experiments. Thirty adult females were rinsed with $4.5 \%$ ammonium formate and transfered into 3 pre-weighed aluminium pans. Samples were dessicated at $60^{\circ} \mathrm{C}$ for $2 \mathrm{~d}$ and then weighed. Total lipid extractions (in triplicate) were performed as described above using 10 females. Each lipid extraction was quantified according to Barnes \& Blackstock (1973), with cholesterol as a standard. Protein was extracted from 15 females (in triplicate) in $\mathrm{NaOH} 0.5 \mathrm{~N}$ and again quantified using a BCA reagent kit with bovine serum albumin as a standard.

Data analysis. F-test (Sokal \& Rohlf 1981) was used to determine the significance of various relationships using linear regression. Difference between samples was tested using either an F-test (1- or 3-way ANOVA with first- and second-order factorial interactions) or a non-parametric Kruskall-Wallis test $(H)$ (Sokal \& Rohlf 1981). In all cases, the alpha level was 0.05 .

\section{RESULTS}

\section{Limiting food conditions}

In the control jars, cell densities did not vary significantly between sampling times $(t=0, t=1 \mathrm{wk}, t=$ 2 wk) as expected from Thalassiosira weissflogii at $6^{\circ} \mathrm{C}$. Significant changes in chlorophyll a concentration could be detected at the Low, Medium and High concentrations ( $n=9, p=0.027$ at each food level). However, protein concentrations remained unchanged (Low: $\mathrm{n}=9, \mathrm{p}=0.393$; Medium: $\mathrm{n}=9, \mathrm{p}=0.733$; High: $\mathrm{n}=9, \mathrm{p}=0.670)$; in other words, the nutritional quality of the food (as protein supplied per cell) was constant throughout the experiment time.

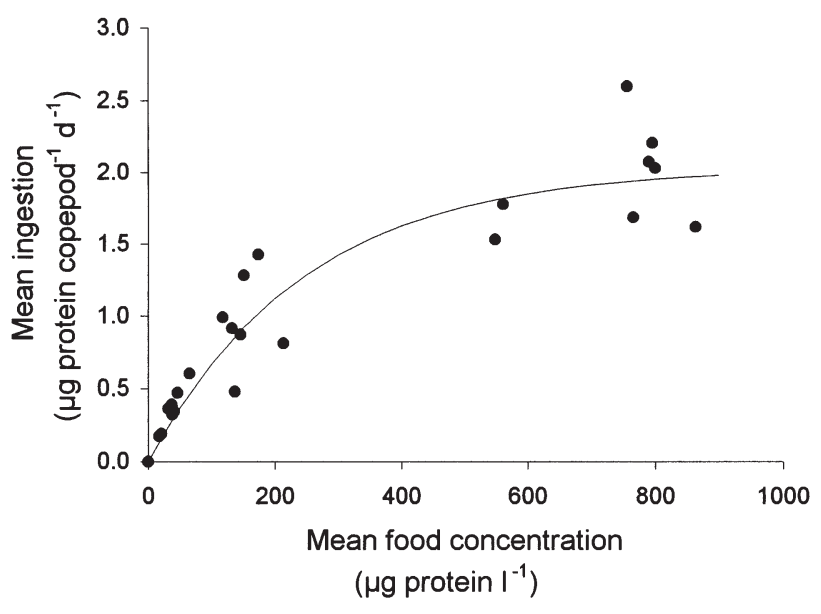

Fig. 1. Drepanopus pectinatus. Mean ingestion $(\mu \mathrm{g}$ protein copepod $^{-1} \mathrm{~d}^{-1}$ ) in relation to the mean food concentration $\left(\mu \mathrm{g}\right.$ protein $\left.\mathrm{l}^{-1}\right)$ in the jars during experiment
In the experimental jars, copepod grazing induced a strong decrease in the food concentration. The concentrations at the end of the experiment were on average 8,17 and $42 \%$ of the initial values at Low, Medium and High food levels, respectively. Therefore, available food supply was strongly time-dependent and became increasingly limiting at all food levels. Food availability in the jars was more accurately expressed using the mean protein concentration during the experiment rather than the initial concentration.

\section{Mean ingestion}

Mean protein concentration <Prot $>$ in the jars could be calculated using a simplified Frost equation (1972) with a growth constant $k=0$ :

$$
<\text { Prot }>=\frac{R_{t} \cdot[\mathrm{chl} a]_{t}-[\text { Prot }]_{t_{0}}}{-g \cdot\left(t-t_{0}\right)}
$$

where $[\text { Prot }]_{t_{0}}$ is the protein concentration $\left(\mu \mathrm{g} \mathrm{l}^{-1}\right)$ in the control jar at $\left.t_{0} ; \mathrm{chl} a\right]_{t}$ is the remaining chlorophyll a concentration $\left(\mu \mathrm{g} \mathrm{l}^{-1}\right)$ in the experiment jar at time $t_{\text {; }}$ $R_{t}$ is the protein to chlorophyll a ratio in the control jar at time $t\left(R_{0}=59, R_{1 \text { week }}=58, R_{2 \text { weeks }}=55\right)$; and $g$ is the grazing coefficient calculated from:

$$
g=-\frac{\ln \left(\frac{R_{t} \cdot[\operatorname{chl} a]_{t}}{[\text { Prot }]_{t_{0}}}\right)}{t-t_{0}}
$$

Mean ingestion $<I>\left(\mu \mathrm{g}\right.$ protein $\left.\mathrm{l}^{-1} \operatorname{copepod}^{-1} \mathrm{~d}^{-1}\right)$ in the jars could be calculated using the following equation:

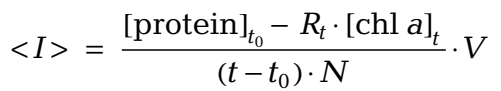

where $N$ is the number of live individuals at time $t$ and $V$ is the volume of the jars.

The relationship between mean protein concentration $<$ Prot $>$ and integrated ingestion $<I>$ is reported in Fig. 1 and could be described using the equation proposed by Ivlev (1955):

$$
<I>=\langle I\rangle_{\max } \cdot\left(1-\mathrm{e}^{-\alpha \cdot<\operatorname{Prot}>}\right)
$$

with the following estimates and 95\% confidence intervals: $\langle I\rangle_{\max }=2.036 \mu \mathrm{g}$ protein copepod $^{-1} \mathrm{~d}^{-1}$, $1.819-2.253 ; \alpha=0.004,0.003-0.006\left(\mathrm{n}=32, \mathrm{R}^{2}=\right.$ $0.92)$.

\section{Biochemical content of females}

Values of dry weight, protein and lipid contents recorded at time of capture are reported for interbrood females in Table 1. No significant differences between dates could be detected in terms of dry weight $(\mathrm{p}=$ 
$0.177)$, protein $(p=0.288)$, or lipid $(p=0.099)(n=9$ with 2 df each time).

The final values of protein, neutral lipid and polar lipid contents are reported in Tables 2 \& 3 for the inter- brood and egg-bearing females respectively. The organic contents were obviously related to food availability. The main effect of the various factors (duration of captivity, preliminary treatment, breeding stage)

Table 1. Drepanopus pectinatus. Dry weight, protein and lipid contents of adult females ( $\mu$ g copepod $\left.{ }^{-1}\right)$ in the field at the dates of capture. At each date: $\mathrm{n}=3, \mathrm{SD}=$ standard deviation, \% DW = percent of the dry weight

\begin{tabular}{|lccccccc|}
\hline $\begin{array}{l}\text { Date of } \\
\text { capture }\end{array}$ & \multicolumn{2}{c}{ Dry weight } & \multicolumn{3}{c}{ Proteins } & \multicolumn{2}{c|}{ Lipids } \\
Mean & SD & Mean & SD & \% DW & Mean & SW \\
\hline 2 Dec 1996 & 63.0 & 7.6 & 34.6 & 5.6 & 55 & 13.1 & 1.1 \\
17 Dec 1996 & 59.7 & 2.3 & 34.6 & 4.0 & 58 & 16.0 & 4.6 \\
3 Jan 1997 & 51.9 & 6.0 & 30.1 & 3.2 & 58 & 21 & 1.2 \\
\hline
\end{tabular}

Table 2. Drepanopus pectinatus. Protein and lipid contents of interbrood females $\left(\mu \mathrm{g}\right.$ copepod $\left.^{-1}\right)$, after 1 or 2 wk, in filtered seawater (starved) or food added at the various concentrations (Low, Medium, High) and in relation to preliminary treatment (acclimated or pre-starved) and date of capture (December or January). SD = standard deviation ( $\mathrm{n}=3$ except nd when material quantity was not sufficient to perform extraction triplicates)

\begin{tabular}{|c|c|c|c|c|c|c|c|c|c|}
\hline \multirow[t]{2}{*}{ Sample } & \multirow{2}{*}{$\begin{array}{l}\text { Feeding } \\
\text { condition }\end{array}$} & \multicolumn{2}{|c|}{ Protein } & \multicolumn{2}{|c|}{ Polar lipids } & \multicolumn{2}{|c|}{ Neutral lipids } & \multicolumn{2}{|c|}{ Total lipids } \\
\hline & & Mean & SD & Mean & $\mathrm{SD}$ & Mean & $\mathrm{SD}$ & Mean & $\mathrm{SD}$ \\
\hline \multicolumn{10}{|c|}{ December } \\
\hline \multicolumn{10}{|c|}{ Acclimated 1 night } \\
\hline \multirow[t]{4}{*}{$1 \mathrm{wk}$} & Starved & 27.4 & 7.7 & 1.8 & 0.1 & 3.5 & 0.1 & 5.3 & 0.3 \\
\hline & Low & 29.9 & 7.0 & 1.5 & 0.2 & 3.8 & 0.5 & 5.2 & 0.3 \\
\hline & Medium & 41.8 & 7.7 & 3.0 & 0.1 & 7.9 & 0.2 & 10.8 & 0.3 \\
\hline & High & 54.9 & 9.2 & 2.0 & 0.3 & 9.3 & 1.3 & 11.3 & 0.2 \\
\hline \multirow[t]{4}{*}{$2 \mathrm{wk}$} & Starved & 25.2 & 7.6 & 1.6 & 0.2 & 2.7 & 0.3 & 4.3 & 0.4 \\
\hline & Low & 26.1 & 6.9 & 1.1 & 0.2 & 3.8 & 0.5 & 4.9 & 0.2 \\
\hline & Medium & 32.1 & nd & 1.8 & 0.2 & 4.4 & 0.5 & 6.1 & 0.3 \\
\hline & High & 37.8 & 3.9 & 2.2 & 0.1 & 12.9 & 0.6 & 15.1 & 0.2 \\
\hline \multicolumn{10}{|c|}{ Pre-starved 2 wk } \\
\hline \multirow[t]{4}{*}{$1 \mathrm{wk}$} & Starved & 21.5 & 4.8 & 1.2 & 0.2 & 1.8 & 0.3 & 3.0 & 0.4 \\
\hline & Low & 29.5 & 4.0 & 1.3 & 0.1 & 2.8 & 0.1 & 4.2 & 0.3 \\
\hline & Medium & 37.2 & 3.9 & 2.0 & 0.4 & 5.0 & 0.9 & 6.9 & 0.3 \\
\hline & High & 45.2 & 6.5 & 2.6 & 0.7 & 7.8 & 1.8 & 10.4 & 0.3 \\
\hline \multirow[t]{4}{*}{$2 \mathrm{wk}$} & Starved & 23.3 & nd & 1.3 & 0.1 & 1.5 & 0.2 & 2.7 & 0.5 \\
\hline & Low & 25.0 & 5.7 & 1.4 & 0.3 & 3.3 & 0.5 & 4.7 & 0.3 \\
\hline & Medium & 29.8 & nd & 1.7 & 0.4 & 4.8 & 1.1 & 6.5 & 0.3 \\
\hline & High & 35.6 & 7.0 & 2.3 & 0.1 & 5.8 & 0.3 & 8.1 & 0.3 \\
\hline \multicolumn{10}{|l|}{ January } \\
\hline \multicolumn{10}{|c|}{ Acclimated 1 night } \\
\hline \multirow[t]{4}{*}{$1 \mathrm{wk}$} & Starved & 28.4 & 4.5 & 2.7 & 0.6 & 3.7 & 0.6 & 6.4 & 0.4 \\
\hline & Low & 30.6 & nd & 2.7 & 1.0 & 5.8 & 2.1 & 8.4 & 0.3 \\
\hline & Medium & 39.7 & 10.6 & 4.0 & 0.3 & 7.8 & 0.9 & 11.8 & 0.3 \\
\hline & High & 54.3 & 1.3 & 3.7 & 0.6 & 9.3 & 1.2 & 13.0 & 0.3 \\
\hline \multirow[t]{4}{*}{$2 \mathrm{wk}$} & Starved & 25.7 & nd & 1.9 & 0.8 & 3.1 & 1.1 & 5.0 & 0.4 \\
\hline & Low & 37.2 & 4.5 & 1.6 & 0.2 & 7.1 & 0.6 & 8.7 & 0.2 \\
\hline & Medium & 32.6 & 6.4 & 3.5 & 0.3 & 8.3 & 0.3 & 11.8 & 0.3 \\
\hline & High & 45.8 & 3.1 & 6.4 & 0.0 & 14.1 & 0.0 & 20.5 & 0.3 \\
\hline \multicolumn{10}{|c|}{ Pre-starved 2 wk } \\
\hline \multirow[t]{4}{*}{$1 \mathrm{wk}$} & Starved & 25.2 & 5.6 & 1.4 & 0.6 & 3.4 & 1.8 & 4.8 & 0.3 \\
\hline & Low & 26.0 & 2.2 & 1.8 & 0.2 & 5.9 & 0.3 & 7.6 & 0.2 \\
\hline & Medium & 43.7 & 2.4 & 2.4 & 0.1 & 7.1 & 0.1 & 9.5 & 0.3 \\
\hline & High & 49.1 & 4.0 & 5.7 & 0.1 & 6.8 & 0.1 & 12.5 & 0.5 \\
\hline \multirow[t]{4}{*}{$2 \mathrm{wk}$} & Starved & 25.7 & 2.2 & 1.9 & 0.4 & 4.2 & 0.8 & 6.0 & 0.3 \\
\hline & Low & 33.6 & 3.6 & 1.8 & 0.5 & 5.8 & 1.5 & 7.6 & 0.2 \\
\hline & Medium & 35.4 & 7.0 & 3.2 & 0.3 & 8.5 & 0.3 & 11.7 & 0.3 \\
\hline & High & 42.9 & 2.8 & 3.8 & 0.1 & 13.7 & 0.5 & 17.5 & 0.2 \\
\hline
\end{tabular}


Table 3. Drepanopus pectinatus. Protein and lipid contents of egg-bearing females ( $\mu$ g copepod ${ }^{-1}$ ), after 1 or 2 wk, in filtered seawater (starved) or food added at the various concentrations (Low, Medium, High) and in relation to preliminary treatment (acclimated or pre-starved) and date of capture (December or January). SD = standard deviation $(\mathrm{n}=3)$

\begin{tabular}{|c|c|c|c|c|c|c|c|c|c|}
\hline \multirow[t]{2}{*}{ Sample } & \multirow{2}{*}{$\begin{array}{l}\text { Feeding } \\
\text { condition }\end{array}$} & \multicolumn{2}{|c|}{ Protein } & \multicolumn{2}{|c|}{ Polar lipids } & \multicolumn{2}{|c|}{ Neutral lipids } & \multicolumn{2}{|c|}{ Total lipids } \\
\hline & & Mean & $\mathrm{SD}$ & Mean & $\mathrm{SD}$ & Mean & $\mathrm{SD}$ & Mean & SD \\
\hline \multicolumn{10}{|c|}{ December } \\
\hline \multicolumn{10}{|c|}{ Acclimated 1 night } \\
\hline \multirow[t]{4}{*}{$1 \mathrm{wk}$} & Starved & 18.5 & 5.8 & 1.8 & 0.5 & 4.1 & 1.1 & 5.9 & 0.3 \\
\hline & Low & 27.4 & 4.5 & 2.0 & 0.2 & 6.4 & 0.6 & 8.3 & 0.2 \\
\hline & Medium & 30.2 & 6.1 & 2.9 & 0.3 & 8.6 & 1.1 & 11.5 & 0.3 \\
\hline & High & 44.9 & 4.1 & 2.7 & 0.2 & 9.8 & 0.9 & 12.5 & 0.2 \\
\hline \multirow[t]{4}{*}{$2 \mathrm{wk}$} & Starved & 22.0 & 5.4 & 1.8 & 0.1 & 3.8 & 0.2 & 5.6 & 0.3 \\
\hline & Low & 25.5 & 7.5 & 1.9 & 0.4 & 5.0 & 1.1 & 6.9 & 0.3 \\
\hline & Medium & 23.7 & 3.1 & 2.2 & 0.3 & 6.5 & 0.7 & 8.6 & 0.3 \\
\hline & High & 32.5 & 2.8 & 4.0 & 0.5 & 16.4 & 1.5 & 20.4 & 0.2 \\
\hline \multicolumn{10}{|c|}{ Pre-starved 2 wk } \\
\hline \multirow[t]{4}{*}{$1 \mathrm{wk}$} & Starved & 24.8 & 3.5 & 1.7 & 0.3 & 2.2 & 0.5 & 3.8 & 0.4 \\
\hline & Low & 30.2 & 2.3 & 2.1 & 0.4 & 3.1 & 0.7 & 5.3 & 0.4 \\
\hline & Medium & 32.6 & 6.6 & 2.7 & 0.7 & 5.1 & 1.3 & 7.9 & 0.4 \\
\hline & High & 35.6 & 9.3 & 1.6 & 0.4 & 10.1 & 1.8 & 11.7 & 0.1 \\
\hline \multirow[t]{4}{*}{$2 \mathrm{wk}$} & Starved & 21.7 & 7.8 & 1.4 & 0.5 & 2.6 & 0.8 & 4.0 & 0.4 \\
\hline & Low & 19.2 & 1.5 & 1.4 & 0.3 & 3.0 & 0.7 & 4.4 & 0.3 \\
\hline & Medium & 22.9 & 2.6 & 1.2 & 0.2 & 3.8 & 0.5 & 5.0 & 0.3 \\
\hline & High & 32.6 & 3.5 & 2.5 & 0.6 & 7.7 & 1.4 & 10.2 & 0.3 \\
\hline \multicolumn{10}{|l|}{ January } \\
\hline \multicolumn{10}{|c|}{ Acclimated 1 night } \\
\hline \multirow[t]{4}{*}{$1 \mathrm{wk}$} & Starved & 23.4 & 4.3 & 1.7 & 0.3 & 5.9 & 0.6 & 7.6 & 0.2 \\
\hline & Low & 26.7 & 11.5 & 2.1 & 0.3 & 5.5 & 0.6 & 7.6 & 0.3 \\
\hline & Medium & 30.3 & 2.7 & 3.3 & 0.5 & 7.7 & 0.8 & 11.0 & 0.3 \\
\hline & High & 44.4 & 7.5 & 3.2 & 0.5 & 8.7 & 1.8 & 11.9 & 0.3 \\
\hline \multirow[t]{4}{*}{$2 \mathrm{wk}$} & Starved & 22.9 & 4.5 & 1.9 & 0.2 & 3.2 & 0.4 & 5.1 & 0.4 \\
\hline & Low & 24.4 & 12.0 & 2.0 & 0.4 & 5.5 & 0.9 & 7.4 & 0.3 \\
\hline & Medium & 32.0 & 7.7 & 2.1 & 0.2 & 8.4 & 0.8 & 10.4 & 0.2 \\
\hline & High & 37.8 & 9.7 & 3.6 & 0.6 & 13.0 & 2.1 & 16.6 & 0.2 \\
\hline \multicolumn{10}{|c|}{ Pre-starved $2 \mathrm{wk}$} \\
\hline \multirow[t]{4}{*}{$1 \mathrm{wk}$} & Starved & 23.7 & 3.6 & 1.9 & 0.4 & 2.8 & 0.6 & 4.7 & 0.4 \\
\hline & Low & 22.2 & 5.4 & 2.2 & 0.1 & 4.3 & 0.4 & 6.4 & 0.3 \\
\hline & Medium & 28.9 & 5.2 & 2.3 & 0.2 & 7.0 & 0.8 & 9.3 & 0.3 \\
\hline & High & 41.2 & 9.4 & 3.0 & 0.3 & 8.8 & 0.6 & 11.7 & 0.3 \\
\hline \multirow[t]{4}{*}{$2 \mathrm{wk}$} & Starved & 20.9 & 7.0 & 1.5 & 0.4 & 3.5 & 0.9 & 5.0 & 0.3 \\
\hline & Low & 24.0 & 8.0 & 1.5 & 0.3 & 5.1 & 0.4 & 6.6 & 0.2 \\
\hline & Medium & 27.1 & 6.7 & 3.1 & 0.3 & 8.1 & 0.7 & 11.2 & 0.3 \\
\hline & High & 37.7 & 12.8 & 3.7 & 0.3 & 13.3 & 1.3 & 16.9 & 0.2 \\
\hline
\end{tabular}

and their possible interactions were investigated secondarily in the starved samples and in the samples fed at the High food level. This analysis was performed with separate values for December 1996 and January 1997. At the High food level, protein contents were significantly greater in the interbrood than in the eggbearing females $(p=0.016)$ and after $1 \mathrm{wk}$ than after $2 \mathrm{wk}(\mathrm{p}=0.001)$. The significant effects detected on lipid contents were not reproducible between December and January.

Protein and lipid proportions (as proportions of the dry weight) varied significantly with female dry weight. The relationships are reported in Fig. 2. The species composition was dominated by protein decreasing from 70 to $55 \%$ with increasing dry weight. Lipids conversely varied in proportion from 10 to $25 \%$ with increasing dry weight and were essentially accumulated in heavy copepods. Neutral and polar lipid proportions were significantly related to total lipids (Fig. 3). Drepanopus pectinatus lipid storage was dominated by neutral lipids (essentially wax esters as shown in Alonzo \& Mayzaud 1999), which accounted for 60 to $85 \%$ of total lipids.

Changes in the protein content of females during experimentation were strongly related to the mean ingestion. The corresponding linear relationship re- 


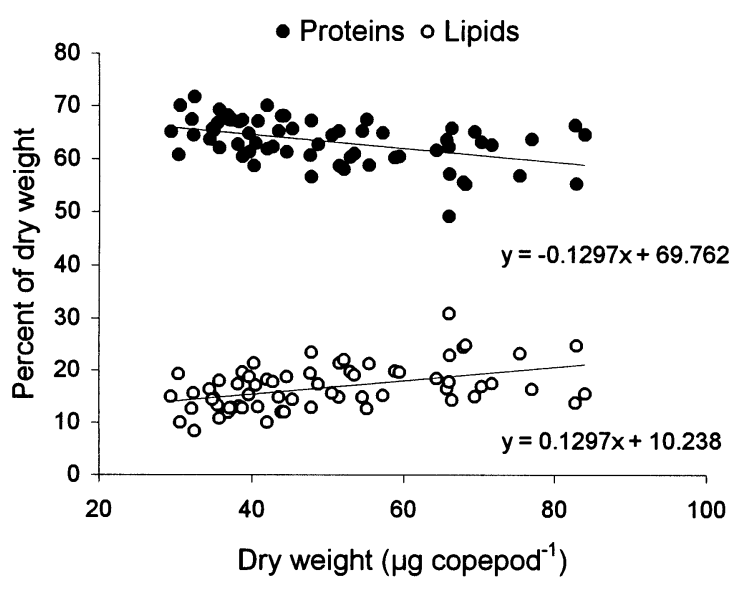

Fig. 2. Drepanopus pectinatus. Protein (๑) and lipid (০) percentages (as percent of the dry weight) in relation to female dry weight $\left(\mu \mathrm{g} \mathrm{copepod}^{-1}\right)$. Dry weight was estimated considering that proteins and lipids accounted for $80 \%$. Regressions: $\mathrm{n}=64, \mathrm{R}^{2}=0.202, F=15.7, \mathrm{p}=0.000$ with $\mathrm{df}=1$ and 62

$$
\text { each time }
$$

ported in Fig. 4 differed significantly according to the duration of captivity $(p=0.000)$. As can be seen in Fig. 4, the quantity of lipids supplied by food was insufficient at each level to achieve a balance in the lipid budget of females.

\section{Biochemical content of eggs}

Protein and lipid contents of eggs were compared between samples to test the possible factorial effects of the preliminary treatment, the duration of captivity, and the level of food supplied. Neither lipids nor proteins showed significant changes. On average $( \pm \mathrm{SD})$, the egg content was $122( \pm 14) \mathrm{ng}$ of proteins and $234( \pm 32) \mathrm{ng}$ of lipids.

\section{Brood size}

In females held individually in $50 \mathrm{ml}$ vials, a difference in brood size was recorded between fed and starved females $(\mathrm{n}=244, \mathrm{p}=0.000)$. Under starvation conditions, the mean brood size was 12.0 eggs per sac, with no significant difference between the 4 successive breeding cycles $(\mathrm{n}=138, \mathrm{p}=0.576)$. In fed females (Medium and High), the mean value was 19.4 eggs per sac, with no difference between the 3 successive breeding cycles or the level of food. However, at the High food level, mean brood size increased significantly to 35.3 eggs per sac during the fourth breeding cycle $(\mathrm{n}=86, \mathrm{p}=0.001)$.

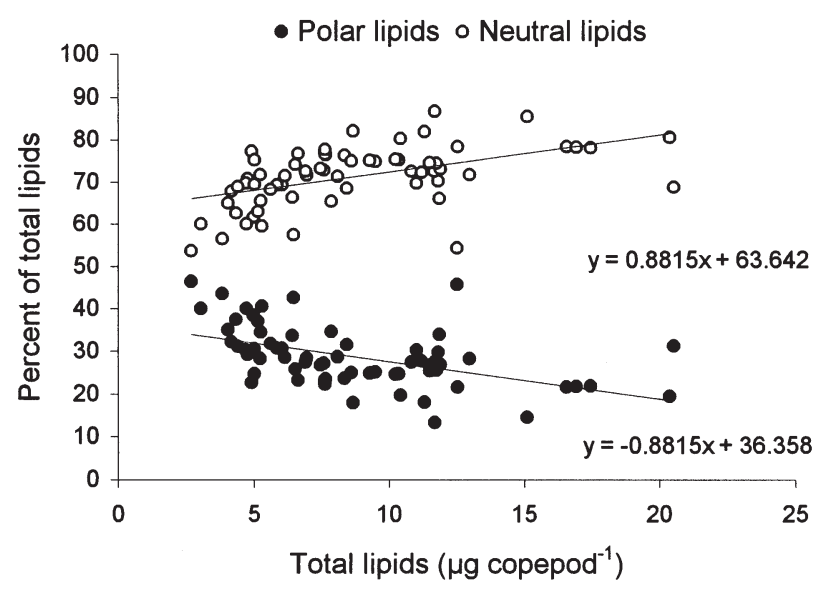

Fig. 3. Drepanopus pectinatus. Polar (•) and neutral (O) lipid percentages (as percent of total lipids) in relation to lipid contents of females $\left(\mu \mathrm{g}\right.$ copepod $\left.^{-1}\right)$. Regressions: $\mathrm{n}=64, \mathrm{R}^{2}=$ $0.242, F=21.15, \mathrm{p}=0.000$ with $\mathrm{df}=1$ and 62 each time

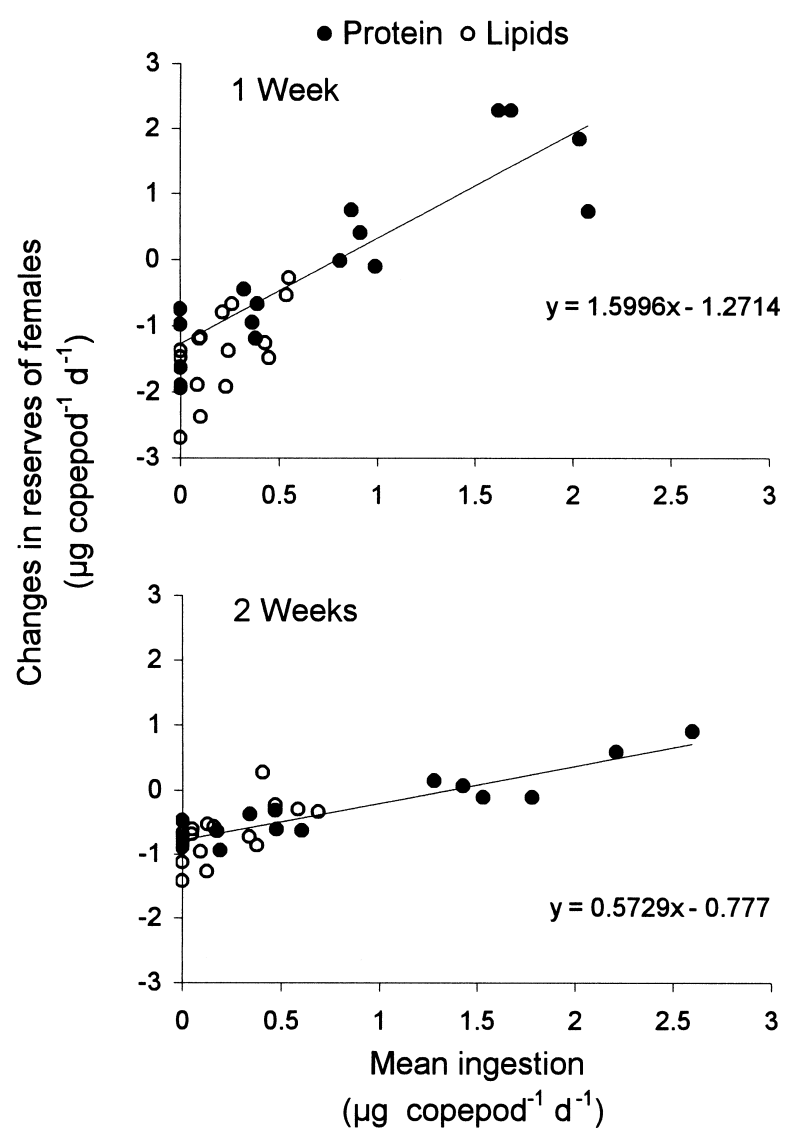

Fig. 4. Drepanopus pectinatus. Changes in protein $(\bullet)$ and lipid (O) contents of females ( $\mu \mathrm{g} \mathrm{copepod}^{-1} \mathrm{~d}^{-1}$ ) in relation to the corresponding quantity ( $\mu$ g copepod ${ }^{-1} \mathrm{~d}^{-1}$ ) supplied by food. Regressions: $n=32, R^{2}=0.792$ to $0.865, p=0.000$ 
Table 4. Drepanopus pectinatus. Mean brood size (SD) $(\mathrm{n}=15)$, percentage of egg-bearing females (as percent of total live individuals) and estimated number of broods produced in jars after 1 or $2 \mathrm{wk}$, in filtered seawater (starved) or food added at the various concentrations (Low, Medium, High) and in relation to preliminary treatment (acclimated or pre-starved) and date of capture (Dec = December 1996; Jan = January 1997)

\begin{tabular}{|c|c|c|c|c|c|c|c|}
\hline \multirow[t]{2}{*}{ Sample } & \multirow[t]{2}{*}{$\begin{array}{l}\text { Feeding } \\
\text { conditions }\end{array}$} & \multicolumn{2}{|c|}{$\begin{array}{c}\text { Number of eggs } \\
\text { per sac }\end{array}$} & \multicolumn{2}{|c|}{$\begin{array}{l}\% \text { egg-bearing } \\
\text { females }\end{array}$} & \multicolumn{2}{|c|}{$\begin{array}{c}\text { Number of broods } \\
\text { per jar }\end{array}$} \\
\hline & & Dec & Jan & Dec & Jan & Dec & Jan \\
\hline \multicolumn{8}{|c|}{ Acclimated 1 night } \\
\hline $1 \mathrm{wk}$ & $\begin{array}{l}\text { Starved } \\
\text { Low } \\
\text { Medium } \\
\text { High }\end{array}$ & $\begin{array}{r}9.8(4.2) \\
11.4(4.9) \\
11.1(4.6) \\
11.2(3.1)\end{array}$ & $\begin{array}{l}10.3(3.7) \\
10.3(3.3) \\
11.5(3.4) \\
12.1(5.1)\end{array}$ & $\begin{array}{l}69 \\
78 \\
69 \\
74\end{array}$ & $\begin{array}{l}72 \\
94 \\
72 \\
84\end{array}$ & $\begin{array}{l}31 \\
35 \\
33 \\
35\end{array}$ & $\begin{array}{l}47 \\
56 \\
38 \\
50\end{array}$ \\
\hline $2 \mathrm{wk}$ & $\begin{array}{l}\text { Starved } \\
\text { Low } \\
\text { Medium } \\
\text { High }\end{array}$ & $\begin{array}{r}8.7(3.6) \\
10.5(4.1) \\
11.3(4.9) \\
12.8(4.4)\end{array}$ & $\begin{array}{r}7.7(3.4) \\
10.1(3.7) \\
11.9(4.9) \\
12.4(4.9)\end{array}$ & $\begin{array}{l}67 \\
77 \\
76 \\
90\end{array}$ & $\begin{array}{l}79 \\
96 \\
75 \\
94\end{array}$ & $\begin{array}{l}52 \\
62 \\
62 \\
86\end{array}$ & $\begin{array}{l}78 \\
92 \\
60 \\
94\end{array}$ \\
\hline \multicolumn{8}{|c|}{ Pre-starved 2 wk } \\
\hline $1 \mathrm{wk}$ & $\begin{array}{l}\text { Starved } \\
\text { Low } \\
\text { Medium } \\
\text { High }\end{array}$ & $\begin{array}{l}8.0(2.9) \\
9.1(3.6) \\
9.3(4.1) \\
9.5(4.0)\end{array}$ & $\begin{array}{r}7.6(3.2) \\
8.6(3.3) \\
9.9(4.3) \\
10.3(4.0)\end{array}$ & $\begin{array}{l}52 \\
59 \\
60 \\
60\end{array}$ & $\begin{array}{l}68 \\
83 \\
62 \\
67\end{array}$ & $\begin{array}{l}26 \\
24 \\
25 \\
28\end{array}$ & $\begin{array}{l}32 \\
34 \\
29 \\
33\end{array}$ \\
\hline $2 \mathrm{wk}$ & $\begin{array}{l}\text { Starved } \\
\text { Low } \\
\text { Medium } \\
\text { High }\end{array}$ & $\begin{array}{l}7.5(3.4) \\
8.8(3.6) \\
9.1(2.7) \\
9.5(4.5)\end{array}$ & $\begin{array}{r}7.5(3.1) \\
8.6(3.1) \\
9.4(4.0) \\
10.4(3.1)\end{array}$ & $\begin{array}{l}72 \\
60 \\
53 \\
85\end{array}$ & $\begin{array}{l}76 \\
72 \\
56 \\
54\end{array}$ & $\begin{array}{l}46 \\
48 \\
52 \\
66\end{array}$ & $\begin{array}{l}45 \\
41 \\
30 \\
41\end{array}$ \\
\hline
\end{tabular}

Table 5. Drepanopus pectinatus. Recruitment of breeding females in relation to feeding conditions. Percentage of breeding females (as percent of total live individuals) is reported in the course of the successive breeding cycles. Date of capture: Dec = December 1996; Jan = January 1997

\begin{tabular}{|lrrrrr|}
\hline \multirow{2}{*}{ Feeding condition } & $\mathrm{n}$ & \multicolumn{3}{c|}{ Percentage of breeding females } & Date of capture \\
& & Brood 1 & Brood 2 & Brood 3 & Dec \\
Starved & 80 & 94 & 78 & 22 & Dec \\
Starved & 14 & 100 & 100 & 50 & Jan \\
Starved & 25 & 96 & 73 & 50 & Jan \\
Medium & 25 & 100 & 100 & 100 & Dec \\
High & 14 & 93 & 100 & 100 & Jan \\
High & 25 & 96 & 100 & & \\
\hline
\end{tabular}

Mean brood sizes observed in females maintained under limiting food conditions ranged from 10.1 to 12.8 eggs per sac (Table 4). Three-way ANOVAs were performed with separate values for December and January. For both December and January, brood sizes were mainly related to food levels and became larger with increasing food concentration ( $p<0.015)$. The number of eggs per sac was also related to the preliminary treatments; smaller brood sizes were observed in females starved for 2 wk before incubation in comparison the acclimated females $(p<0.001)$. The duration of the experiment did not influence brood size. No significant interaction could be detected among factors.

\section{Egg production dynamics}

Recruitment of reproductive females in the course of the experiments differed greatly between fed and starved conditions (Table 5). Fed females at either High or Medium food levels produced 3 successive broods. Under starving conditions, the proportion of breeding females progressively decreased during the experiments, with 22 to $50 \%$ of the live females producing a third brood. This decrease could be interpreted as the progressive consumption of energy reserves of females invested in reproduction.

The duration of the interval between production of 2 successive egg sacs was relatively constant between 


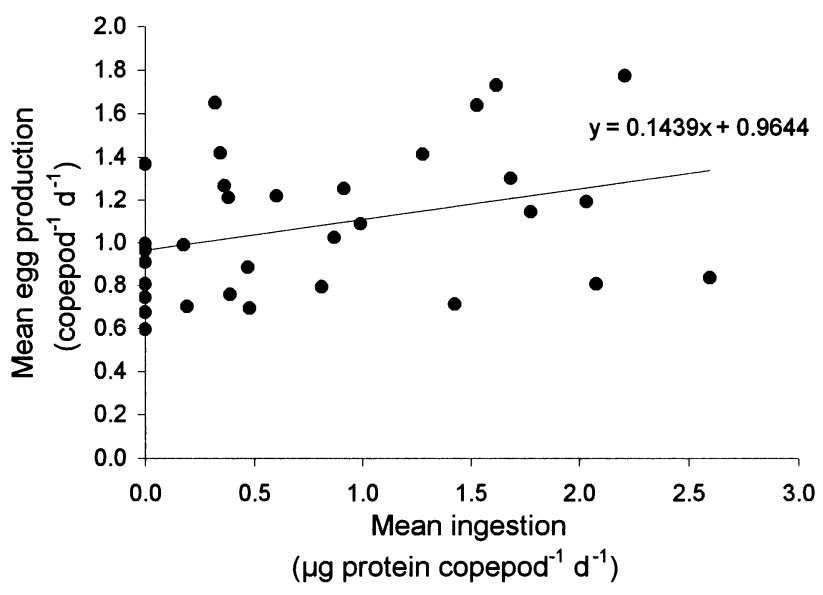

Fig. 5. Drepanopus pectinatus. Mean number of eggs produced (per copepod and per day) in relation to ingestion $\left(\mu \mathrm{g}\right.$ protein copepod $\left.{ }^{-1} \mathrm{~d}^{-1}\right)$. Regression: $\mathrm{n}=32, \mathrm{R}^{2}=0.11, F=$ 3.608, $\mathrm{p}=0.067$ with $\mathrm{df}=1$ and 30

females and varied neither in relation to collection date, breeding cycle, nor feeding conditions $(n=148$, $\mathrm{p}=0.718)$. On average, females took $7.6 \mathrm{~d}(\mathrm{SD}=1.4)$ to produce an egg sac. Similarly, the time taken for eggs to hatch was constant between conditions ( $\mathrm{n}=156, \mathrm{p}=0.453)$, with a mean value of $6.7 \mathrm{~d}(\mathrm{SD}=1.1)$.

\section{Hatching success}

No visible influences resulting from feeding condition, breeding cycle or duration of captivity were observed on hatching success. On average, $91 \%$ of the broods showed 90 to $100 \%$ hatched eggs. Only $5 \%$ of ovisacs yielded a low proportion of hatched eggs ( 0 to $20 \%$ ).

\section{Energy budget}

The proportion of interbrood and eggbearing females observed in the $1 \mathrm{l}$ jars and the associated estimated number of broods are reported in Table 4 . The mean egg production in the jars was calculated per copepod on a daily basis and plotted against the mean ingestion of protein (Fig. 5). The linear relationship described was not significant, i.e. on the investigated range of limiting conditions, egg production did not vary with protein intake.

The energy budget was estimated using the energy equivalents given by Winberg
(1971): $23.6 \mathrm{~J} \mathrm{mg}^{-1}$ protein and $39.5 \mathrm{~J} \mathrm{mg}^{-1}$ lipid. Total energy (protein and lipid) associated with the production of eggs and changes in stored reserves of females (accumulation or consumption) was calculated and plotted against the total energy supplied through feeding (Fig. 6). On one hand, the expenditure of the energy reserves stored in females was strongly related to the quantity of energy supplied by food, and on the other hand, the energy invested in egg production was not significantly related to energy supplied by food, with a mean value of $13.110^{-3} \mathrm{~J}_{\text {copepod }}^{-1} \mathrm{~d}^{-1}$. A minimum of $6510^{-3} \mathrm{~J}_{\text {copepod }}{ }^{-1} \mathrm{~d}^{-1}$ (corresponding to the ingestion of $1.9 \mu \mathrm{g}$ protein and $0.5 \mu \mathrm{g}$ lipids cope$\operatorname{pod}^{-1} \mathrm{~d}^{-1}$ ) was necessary for females to accumulate energy reserves.

\section{DISCUSSION}

\section{Experimental food conditions}

In this study, we examined egg production of Drepanopus pectinatus in relation to its food supply. The range of food concentrations investigated was consis-

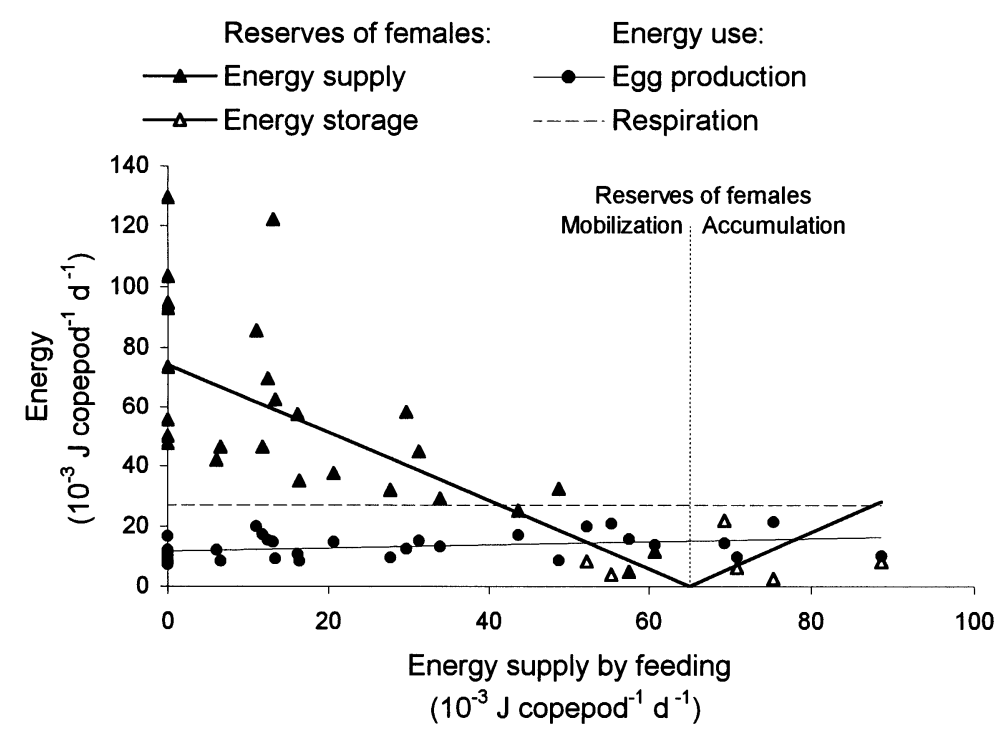

Fig. 6. Drepanopus pectinatus. Daily energy budget. Mobilization and accumulation of energy reserves of females, energy invested in egg production and respiratory loss in relation to energy supplied through ingestion. Food supply, reserves of females and reproductive investment are calculated from protein and lipid contents of food, females and eggs. Dashed line shows a calculated respiratory loss considering the mean oxygen consumption of $0.059 \mu \mathrm{Ol}_{2}$ female $\mathrm{e}^{-1} \mathrm{~h}^{-1}$ observed by Razouls (1985) and the energy equivalent of $19.38 \mathrm{~J} \mathrm{ml} \mathrm{O}_{2}^{-1}$ (Båmstedt 1979). Regression of egg production: $y=0.05 x+11.69 ; \mathrm{n}=32, \mathrm{R}^{2}=0.11, F=3.87, \mathrm{p}=0.059$ with df 1 and 30. Changes in energy reserves: $y>0$ when reserves are mobilized and $y<0$ when reserves are accumulated; regression: $y=77.40$ $-1.19 x ; \mathrm{n}=32, \mathrm{R}^{2}=0.68, F=63.6, \mathrm{p}=0.000$ with $\mathrm{df}=1$ and 30 ; regression lines reports absolute values $|y|$ 
tent with concentrations of chlorophyll $a$ and protein occurring in natural conditions (Razouls et al. 1996, Mayzaud unpubl. data). We also examined changes in energy reserves of females in relation to food limitation. Food limitation was induced by strong decreases in food concentration as a result of grazing. Both food availability and ingestion of copepods were timedependent and the limitation could be observed in the ingestive response of copepods. Thus, the Ivlev equation describing the relationship between mean food availability and mean ingestion yielded values of $\langle I\rangle_{\text {max }}$ and $\alpha$, which were much lower than those expected from ingestion rate experiments (with incubations performed for only a few hours; Mayzaud et al. 1992).

\section{Influence of food on egg production}

Our experiments showed that in Drepanopus pectinatus egg production was influenced by the food concentration supplied. In females maintained in $50 \mathrm{ml}$ vials, the number of eggs per sac increased significantly between starved and fed females. Furthermore, females fed at the High food level strongly increased their brood sizes in production of the 4 th brood. Similarly, a lag time was observed in the arctic Calanus glacialis (Hirche \& Kattner 1993), where spawning rates increased strongly in fed females after $10 \mathrm{~d}$. The interval between production of 2 successive broods was constant in D. pectinatus. This observation contrasts with the results from $C$. finmarchicus, for which the egg production rate was regulated by changes in spawning frequency (Hirche et al. 1997).

Egg-hatching time was independent of the feeding conditions. The mean value recorded was higher than that observed in other egg-carrying calanoid species at $15^{\circ} \mathrm{C}$ (Kiørboe \& Sabatini 1994). This difference could be related to the influence of temperature on growth rates (Huntley \& Lopez 1992).

In 11 jars, brood size was significantly related to the food level and the preliminary treatment. This result demonstrated that reproduction was influenced by both immediate and past feeding conditions. Similarly, when Acartia tonsa females were starved for 3 to $5 \mathrm{~d}$, a lag time of 8 to $11 \mathrm{~d}$ was necessary before egg production recovered its normal rate (Calbet \& Alcaraz 1996). Fluctuating or intermittent food supply was similarly shown to affect egg production rates in Calanus australis (Attwood \& Peterson 1989). In Drepanopus pectinatus, the periods of food limitation showed a strong influence on production of eggs. In fact, brood sizes were smaller in 11 jars at 'High' food levels than in $50 \mathrm{ml}$ vials at constant 'Medium' food levels although phytoplankton concentration was greater (even after the copepods had grazed for $1 \mathrm{wk}$ ).

\section{Influence of food on organic content of females}

In Calanus pacificus, Lee et al. (1971) described a linear relationship between total lipid contents and available food concentrations. Triglyceride content was shown to be a good indicator of recent feeding conditions (less than $3 \mathrm{~d}$ ), while wax esters reflected feeding over a $1 \mathrm{wk}$ period (Håkanson 1984). Similarly, we found that in Drepanopus pectinatus, both protein and lipid contents were strongly associated with available food concentration. Protein content of females was a good indicator of immediate feeding conditions. No difference could be detected between pre-starved and acclimated females after a 1 wk feeding period, suggesting that recovery lag time was short. This result might reflect the biochemical composition of the food used, the diatom Thalassiosira weissflogii, which is dominated by protein. Conversely, lipids were shown to reflect past feeding conditions. In fact, lipid contents of females showed differences in relation to both food supply levels and preliminary treatments, with lower recorded values in the pre-starved than in acclimated individuals. The persistence of these differences even after a feeding period of 2 wk suggests a relatively slow metabolism of wax esters. This was observed in C. helgolandicus: waxes were synthesised after 1 to $4 \mathrm{~d}$ of exposure to concentrated food and their catabolism required 2 to $7 \mathrm{~d}$ of starvation (Sargent et al. 1977, Håkanson 1984).

\section{Role of energy reserves of females}

In Neocalanus tonsus (Ohman 1987) and in Calanus glacialis (Hirche \& Kattner 1993), females from winter were shown to produce eggs when placed in filtered seawater, whereas those from spring could not and required a particulate food source. Our study showed that Drepanopus pectinatus from spring followed a different pattern: starved females maintained egg production at a minimal level, using their accumulated reserves. Reproductive requirements were 2-fold: reproduction under a prolonged period of starvation induced a strong decrease in both protein and lipid content of females. As the food used was poor in lipids, lipid contents of fed females decreased in all cases except 1 fed at 'High' food level. An effect of reproductive requirements was also suggested by protein contents of fed females. In fact, mean values recorded were higher in interbrood than in egg-bearing females. For fed females, as the proportion of breeding females increased the protein content of 
females decreased. Thus, the protein supplied by food was quickly invested in reproduction.

\section{Reproductive strategy}

Drepanopus pectinatus in the Kerguelen islands was shown to complete 4 generations $\mathrm{yr}^{-1}$ (Razouls \& Razouls 1988, 1990). The reproductive response in relation to feeding and starvation conditions might differ between generations. However, the possibility of overlapping generations is difficult to test and was not considered in the present study. As the abundance of copepods showed a 100-fold factor increase from winter to summer, the proportion of winter females in the summer population should be negligible. Thus, we concluded that the $D$. pectinatus energy source for reproduction during summer was 2-fold: egg production was supported either by immediate feeding or from energy reserves of the females. The relative contribution of each energy source depended on immediate availability of food and on past feeding conditions. When particulate matter was in limited supply or absent, egg production was maintained at a minimal level and relied on the energy reserves of the females. Food supplied at a higher level or after a starvation period did not induce a significant increase in egg production, but was used to reduce consumption of the reserves of the females. Our results strongly suggested that at saturating of food concentrations, the energy storage of females reaches a maximum. Further ingestion is entirely invested in egg production, resulting in increasing brood size, as observed in $50 \mathrm{ml}$ vials.

The reproductive biology of the copepod Drepanopus pectinatus is adapted to a predictable food environment with possible short periods of limitation. When food supply is sufficient, the strategy of the species attempts to store energy reserves in females. This energy storage can be used subsequently to achieve a continuous egg production when food availability is temporarily low. Eggs are constantly produced with large lipid and protein reserves and show a high hatching rate. This strategy is consistent with the observation of a relatively long time of brood attachment to the mother, which suggests a high degree of maternal care.

Acknowledgements. We would like to thank Dr M. Ohman and Dr E. Rochelle-Newall for commenting on and editing the manuscript and Mr Gildas Roudaut for technical assistance. Financial support was provided by IFRTP as part of the program IOZ. Our thanks also go to the captains and crews of the RV 'La Curieuse' and to Mr Gilles Cauvin and Pascal Lejeune for their assistance during sampling. The authors are grateful to anonymous referees for their helpful comments on this manuscript.

\section{LITERATURE CITED}

Alonzo F, Mayzaud P (1999) Spectrofluorometric quantification of neutral and polar lipids in zooplankton using Nile red. Mar Chem 67:289-301

Alonzo F, Mayzaud P, Razouls S (2000) Egg production, population structure and biochemical composition of the subantarctic copepod Paraeuchaeta antarctica in the Kerguelen Archipelago. Mar Ecol Prog Ser 205:207-217

Andrews KJ (1966) The distribution and life history of Calanoides acutus (Giesbrecht). Discovery Rep 34:117-162

Attwood CG, Peterson WT (1989) Reduction in fecundity and lipids of the copepod Calanus australis (Brodskii) by strongly pulsed upwelling. J Exp Mar Biol Ecol 129: 121-131

Båmstedt U (1979) Reproductive bioenergetics within the summer and winter generations of Euchaeta norvegica (Copepoda). Mar Biol 54:135-142

Barnes H, Blackstock J (1973) Estimation of lipids in marine animals and tissues: detailed investigation of the sulfovanillin method for total lipids. J Exp Mar Biol Ecol 12: $103-118$

Bligh EG, Dyer WJ (1959) A rapid method of total lipid extraction and purification. Can J Biochem Physiol 37:911-917

Böhlen P, Stein S, Dairman W, Udenfriend S (1973) Fluorometric assay of proteins in the Nanogram Range. Arch Biochem Biophys 155:213-220

Calbet A, Alcaraz M (1996) Effects of constant and fluctuating food supply on egg production rates of Acartia grani (Copepoda: Calanoida). Mar Ecol Prog Ser 140:33-39

Conover RJ (1988) Comparative life histories in the genera Calanus and Neocalanus in high latitudes of the northern hemisphere. Hydrobiologia 167/168:127-142

Diel S, Tande K (1992) Does the spawning of Calanus finmarchicus in high latitudes follow a reproducible pattern? Mar Biol 113:21-31

Frost BW (1972) Effects of size and concentration of food particles on the feeding behaviour of the marine planktonic copepod Calanus pacificus. Limnol Oceanogr 17: 805-815

Guillard RRL, Ryther JH (1962) Studies in the marineplanktonic diatoms. I. Cyclotella nana (Hustedt) and Detonula confervacea (Cleve). Gran Can J Microbiol 8:229-239

Håkanson JL (1984) The long and short term feeding condition in field-caught Calanus pacificus, as determined from the lipid content. Limnol Oceanogr 29:794-804

Hirche HJ, Kattner G (1993) Egg production and lipid content of Calanus glacialis in spring: indication of a food-dependent and food-independent reproductive mode. Mar Biol 117:615-622

Hirche HJ, Meyer U, Niehoff B (1997) Egg production of Calanus finmarchicus: effect of temperature, food and season. Mar Biol 127:609-620

Holm-Hansen O, Lorenzen CJ, Holmes RW, Srickland JD (1965) Fluorometric determination of chlorophyll. J Cons Int Explor Mer 30:3-15

Hülsemann K (1985) Two species of Drepanopus Brady (Copepoda: Calanoida) with discrete ranges in the Southern Hemisphere. J Plankton Res 7:909-925

Huntley M, Escritor F (1991) Dynamics of Calanoides acutus (Copepoda: Calanoida) in Antarctic coastal waters. DeepSea Res 38A:1145-1167

Huntley ME, Lopez MDG (1992) Temperature-dependent production of marine copepods: a global synthesis. Am Nat 140:201-242

Ivlev VS (1955) Experimental ecology of the feeding of fishes. Yale University Press, New Haven 
Kiørboe T, Sabatini M (1994) Reproductive and life cycle strategies in egg-carrying cyclopoid and free-spawning calanoid copepods. J Plankton Res 16:1353-1366

Lee RF, Hirota J (1973) Wax esters in tropical zooplankton and nekton and the geographical distribution of wax esters in marine copepods. Limnol Oceanogr 18:227-239

Lee RF, Nevenzel JC, Paffenhöfer GA (1971) Importance of wax esters and other lipids in the marine food chain: phytoplankton and copepods. Mar Biol 9:99-108

Lorenzen CJ (1966) A method for the continuous measurement of in vivo chlorophyll concentration. Deep-Sea Res 13:223-227

Mayzaud P, Martin JLM (1975) Some aspects of the biochemical and mineral composition of marine plankton. J Exp Mar Biol Ecol 17:297-310

Mayzaud P, Roche-Mayzaud O, Razouls S (1992) Medium term time acclimation of feeding and digestive enzyme activity in marine copepods: influence of food concentration and copepod species. Mar Ecol Prog Ser 89: $197-212$

Neveux J (1976) Dosage de la chlorophylle a et de la phéophytine a par fluorimétrie. Ann Inst Oceanogr 52:165-174

Ohman MD (1987) Energy sources for recruitment of subantarctic copepod Neocalanus tonsus. Limnol Oceanogr 32:1317-1330

Ohman M, Bradford JM, Jillett JB (1989) Seasonal growth and lipid storage of the circumglobal, subantarctic copepod Neocalanus tonsus (Brady). Deep-Sea Res 36A:1309-1326

Ommaney FD (1936) Rhincalanus gigas (Brady), a copepod of the southern macroplankton. Discovery Rep 13:277-384

Pande SV, Parvin Khan R, Venkitasubramanian TA (1963) Microdetermination of lipids and serum total fatty acids. Anal Biochem 6:317-332

Razouls C, Razouls S (1990) Biological cycle of a population of

Editorial responsibility: Otto Kinne (Editor),

Oldendorf/Luhe, Germany subantarctic copepod, Drepanopus pectinatus (Clausocalanidae), Kerguelen Archipelago. Polar Biol 10:541-543

Razouls S (1985) Observations on the ecophysiology of a planktonic crustacean, Drepanopus pectinatus (Copepoda, Calanoida, Pseudocalanidae), from southern islands. In: Gray JS, Christiansen ME (eds) Marine biology of polar regions and effects of stress on marine organisms. John Wiley \& Sons, Ltd, Chichester, p 123-139

Razouls S, Razouls C (1988) Seasonal size distribution of developmental stages of sub-antarctic copepod. Hydrobiologia 167/168:239-246

Razouls S, Koubbi P, Mayzaud P (1996) Spatio-temporal distribution of mesozooplankton in a sub-Antarctic coastal basin of the Kerguelen Archipelago (southern Indian Ocean). Polar Biol 16:581-587

Sargent JR, Henderson RJ (1986) Lipids. In: Corner EDS, O'Hara SCM (eds) The biological chemistry of marine copepods. Clarendon Press, Oxford, p 59-108

Sargent JR, Gatten RR, Corner EDS, Kilvington CC (1977) On the nutrition and metabolism of zooplankton XI. Lipids in Calanus helgolandicus grazing Biddulpha sinensis. J Mar Biol Assoc UK 57:525-533

Smith SL (1990) Egg production and feeding by copepods prior to the spring bloom of phytoplankton in Fram Strait, Greenland Sea. Mar Biol 106:59-69

Sokal RR, Rohlf FJ (1981) Biometry, 2nd edn. WH Freeman, San Francisco

Winberg GG (1971) Methods for the estimation of production of aquatic animals. Academic Press, London

Yen J (1991) Predatory feeding behaviour of an Antarctic marine copepod, Euchaeta antarctica. Polar Res 10:433-442

Yentsch CS, Menzel DW (1963) A method for the determination of phytoplankton chlorophyll and phaeophytin by fluorescence. Deep-Sea Res 10:221-231

Submitted: February 16, 2000; Accepted: June 8, 2000

Proofs received from author(s): November 30, 2000 